\title{
Thermal radical polymerization of Bis(methacrylamide)s
}

\author{
Stéfani Becker Rodrigues ${ }^{1}$, Fabrício Mezzomo Collares ${ }^{1}$, Douglas Gamba ${ }^{2}$, Vicente Castelo Branco Leitune ${ }^{1}$ \\ and Cesar Liberato Petzhold*
}

\section{${ }^{1}$ Laboratório de Materiais Dentários, Faculdade de Odontologia, Universidade Federal do Rio Grande do Sul - UFRGS, Porto Alegre, RS, Brasil \\ ${ }^{2}$ Departamento de Química Orgânica, Instituto de Química, Universidade Federal do Rio Grande do Sul - UFRGS, Porto Alegre, RS, Brasil \\ *petzhold@iq.ufrgs.br}

\begin{abstract}
Methacrylamides monomers for dental applications were synthesized using a one-step procedure starting from methacrylic anhydride and the respective diamine: $N, N$ '-(propane-1,3-diyl)-bis(N-ethyl-2-methylacrylamide) (1), $N, N$ '(butane-1,4-diyl)-bis(2-methacrylamide) (2), $N, N^{\prime}$-(octane-1,8-diyl-)bis(2-methylacrylamide) (3) and $N, N^{\prime}$-(1,4-phenylene)bis(2-methylacrylamide) (4). The structures were confirmed by ${ }^{1} \mathrm{H}$ NMR, ${ }^{13} \mathrm{C}$ NMR, FTIR-ATR and UHPLC-QTOF-MS. Thermal polymerization kinetics was investigated by modulated DSC for monomers (2), (3) and (4) using heating rates of $1,2,3$ and $5{ }^{\circ} \mathrm{C} \mathrm{min}^{-1}$. All IR spectra showed the $\mathrm{C}=\mathrm{C}$ axial deformation at $1610 \mathrm{~cm}^{-1}$, in ${ }^{1} \mathrm{H}$ NMR spectra the olefinic hydrogens were observed at 5.3 an $5.8 \mathrm{ppm}$ and in ${ }^{13} \mathrm{C}$ NMR, the vinylic carbons at 120 and $140 \mathrm{ppm}$. The exact $\mathrm{m} / \mathrm{z}$ values were: $267.2068,225.1595,281.2222$ and 245.1283 for monomers (1), (2), (3) and (4), respectively. The activation energy was: -182.7 ; -165.8 and $-156.7 \mathrm{~kJ} \mathrm{~mol}^{-1}$ for monomers (2), (3) and (4), respectively. Monomers are promising candidates for use as hydrolytic stable adhesive systems for dental applications.
\end{abstract}

Keywords: adhesives, monomers, kinetics, differential scanning calorimetry (DSC), synthesis.

How to cite: Rodrigues, S. B., Collares, F. M., Gamba, D., Leitune, V. C. B., \& Petzhold, C. L. (2019). Thermal radical polymerization of Bis(methacrylamide)s. Polímeros: Ciência e Tecnologia, 29(2), e2019023. https://doi.org/10.1590/0104-1428.03218

\section{Introduction}

Dental hard tissues (enamel and dentin) achieve a strong bond with restoratives polymers by means of dental adhesives. These dental adhesives are compounds of hydrophilic and hydrophobic monomers, photoinitiators and solvents ${ }^{[1]}$. Crosslinking dimethacrylates and acrylates are the most commonly monomers used in adhesives due to improvement of polymerization reactivity and material properties $^{[2-4]}$. The long-term durability of adhesive/dentin interface depends on the functional monomers and polymer chain integrity ${ }^{[5,6]}$. However, the methacrylate monomers present low hydrolytic stability mainly in acid environments as in single-bottle adhesive ${ }^{[7-9]}$.

In this respect, methacrylamides and acrylamides were synthesized due to the hydrolytic stable amide group instead of an ester group, and also to their similarity to the amino acids as collagen fibrils that could facilitate hydrogen bond between collagen and amide groups ${ }^{[9-15]}$. Bis(acrylamide)s and bis(methacrylamide)s have been synthesized via acryloyl chloride or methacryloyl chloride with diamines resulting sometimes in solid monomers, with a very low solubility in organic solvents and difficult purification ${ }^{[16-22]}$. In this context, suitable liquid bis-(acrylamide) s $N, N$ '-diethyl-1,3-bis(acrylamido)propane (DEAAP), $N, N$ '-dimethyl-1,3-bis(acrylamido)propane (DMAAP), and $N, N$ '-dimethyl-1,6-bis(acrylamido)hexane (DMAAH) were synthesized as substitute to methacrylates commonly used in adhesive systems such as TEGDMA (triethylene glycol dimethacrylate) or HEMA (2-hydroxyethyl methacrylate) and improving hydrolytic stability of dental adhesives ${ }^{[16,23,24]}$.

Monomers with reactivity, obtained with good yields and synthesized by one-step synthetic route are important to development of simplified dental adhesives. Thus, the aim of this study is the synthesis of hydrolytically stable bis(methacrylamide) monomers for dental applications by one-step synthetic route and the investigation their kinetic thermal polymerization by DSC using Kissinger methodology ${ }^{[23]}$.

\section{Materials and Methods}

\section{1 Materials}

$N, N^{\prime}$-diethyl-1,3-propanediamine, methacrylic anhydride and 4-(dimethylamino)pyridine were purchased from Sigma-Aldrich and used without any further purification. 1,8-diaminooctane, 1,4-diaminobutane and $p$-phenylenediamine were purchased from Alfa Aesar and also used without any further purification. Triethylamine and solvents as dichloromethane, tetrahydrofuran, hexane and ethyl acetate were purchased from local suppliers. Dichloromethane was dried by refluxing with calcium hydride and further 
distillation under $\mathrm{N}_{2}$ atmosphere. Column chromatography was performed using Silica gel Si 70 - 230 Mesh (supplied by Sigma Aldrich) as stationary phase.

\subsection{Monomer synthesis}

Synthesis of $N, N^{\prime}$-(propane-1,3-diyl)-bis(N-ethyl-2methylacrylamide) (1)

To a solution of $N, N^{\prime}$-diethyl-1,3-propanediamine ( $0.5 \mathrm{~g} ; 3.84 \mathrm{mmol})$, triethylamine (1.5 eq.) and 4-(dimethylamino) pyridine ( $5 \mathrm{~mol} \%$ ) in $12 \mathrm{~mL}$ of anhydrous dichloromethane, a solution of methacrylic anhydride (1.5 eq.) in $12 \mathrm{~mL}$ of anhydrous dichloromethane was added dropwise in an ice bath. After 16 hours at room temperature, $6 \mathrm{~mL}$ of water was added and the solution was extracted with dichloromethane $(3 \times 5 \mathrm{~mL})$. After drying the organic phase with anhydrous $\mathrm{Na}_{2} \mathrm{SO}_{4}$, the solvent was removed in rotatory evaporator. The crude product was purified by column chromatography, eluting with hexane:ethyl acetate (70:30) to give monomer (1) as yellow viscous oil. Yield: $50 \%$. ${ }^{1} \mathrm{H} \mathrm{NMR}\left(400 \mathrm{MHz}, \mathrm{CDCl}_{3}\right)$ $\delta(\mathrm{ppm}): 5.10(\mathrm{~s}, 2 \mathrm{H}) ; 5.01$ (s, 2H), $3.51-3.25(\mathrm{~m}, 8 \mathrm{H})$; $1.97(\mathrm{~m}, 6 \mathrm{H}) ; 1.85(\mathrm{~m}, 2 \mathrm{H}) ; 1.15(\mathrm{t}, J=7.1 \mathrm{~Hz}, 6 \mathrm{H}) .{ }^{13} \mathrm{C} \mathrm{NMR}$ $\left(100 \mathrm{MHz}, \mathrm{CDCl}_{3}\right) \delta$ (ppm): 172.5 (2); 141.1 (2); 114.3 (2); 114.3 (2); 43.1 (2); 41.4 (2); 27.6 (2); 20.6 (2); 14.3 (2). (2)

Synthesis of $N, N$ '-(butane-1,4-diyl)-bis(2-methacrylamide)

A solution of methacrylic anhydride (2.1 eq.) of dry dichloromethane $(10 \mathrm{~mL})$ was added dropwise to a solution of 1,4-diaminobutane $(0.510 \mathrm{~g} ; 57.72 \mathrm{mmol})$ and triethylamine (2.1 eq.) in dry dichloromethane $(30 \mathrm{~mL})$ in an ice bath. After stirring 16 hours at room temperature, water $(10 \mathrm{~mL})$ was added to the reaction and the aqueous phase was extracted with dichloromethane $(3 \times 10 \mathrm{~mL})$. After drying the organic phase with anhydrous $\mathrm{Na}_{2} \mathrm{SO}_{4}$ the solvent was evaporated. The crude product was purified by precipitation in hexane to afford monomer (2) as a white solid. Yield: $61 \%$. ${ }^{1} \mathrm{H}$ NMR (400 MHz, $\left.\mathrm{CDCl}_{3}\right) \delta(\mathrm{ppm})$ : $6.27(\mathrm{~s}, 2 \mathrm{H}) ; 5.69$ (s, 2H); 5.32 (s, 2H); 3.34 (q, J=6.2 Hz, 4H); $1.96(\mathrm{~s}, 6 \mathrm{H}) ; 1.60(\mathrm{~m}, 4 \mathrm{H}) .{ }^{13} \mathrm{C}$ NMR $\left(100 \mathrm{MHz}, \mathrm{CDCl}_{3}\right)$ $\delta$ (ppm): 168.7 (2); 140 (2); 119.4 (2); 39.2 (2); 26.9 (2); 18.7 (2). Mp: $127.4^{\circ} \mathrm{C}$. (3)

Synthesis of $N, N^{\prime}$-(octane-1,8-diyl-)-bis(2-methylacrylamide)

A solution of methacrylic anhydride (2.5 eq.) in dry dichloromethane $(10 \mathrm{~mL})$ was added dropwise to a solution of 1,8-diaminooctane $(0.510 \mathrm{~g} ; 3.46 \mathrm{mmol})$ and triethylamine (3.5 eq.) in $30 \mathrm{~mL}$ of dry dichloromethane in an ice bath. After stirring 16 hours at room temperature, water $(10 \mathrm{~mL})$ was added to the reaction and the aqueous phase was extracted with dichloromethane $(3 \times 10 \mathrm{~mL})$. After drying the organic phase in anhydrous $\mathrm{Na}_{2} \mathrm{SO}_{4}$ the solvent was removed in rotatory evaporator. The crude product was purified by precipitation in hexane to afford monomer (3) as a white solid. Yield: $48 \%$. ${ }^{1} \mathrm{H}$ NMR (400 MHz, $\left.\mathrm{CDCl}_{3}\right) \delta(\mathrm{ppm})$ : $6.05(\mathrm{~s}, 2 \mathrm{H}) ; 5.67(\mathrm{~s}, 2 \mathrm{H}) ; 5.30(\mathrm{~s}, 2 \mathrm{H}) ; 3.28(\mathrm{q}, J=6.8 \mathrm{~Hz}, 4 \mathrm{H})$; $1.96(\mathrm{~s}, 6 \mathrm{H}) ; 1.53$ (qt, $J=6.8 \mathrm{~Hz}, 4 \mathrm{H}) ; 1.32(\mathrm{~m}, 8 \mathrm{H})$. ${ }^{13} \mathrm{C}$ NMR (100 MHz, CDCl3) $\delta$ (ppm): 168.5 (2); 140.3 (2); 119.1 (2); 39.7 (2); 29.5 (2); 29.1 (2); 26.8 (2); 18.7 (2). Mp: $109.2{ }^{\circ} \mathrm{C}$.
Synthesis of $N, N$ '-(1,4-phenylene)-bis(2-methylacrylamide) (4)

To a solution of $p$-phenylenediamine $(0.515 \mathrm{~g} ; 4.62 \mathrm{mmol})$ and triethylamine (3.5 eq.) in $30 \mathrm{~mL}$ of anhydrous dichloromethane, was added dropwise a solution of methacrylic anhydride (3.5 eq.) in anhydrous dichloromethane $(10 \mathrm{~mL})$ in an ice bath for 30 minutes. After stirring 16 hours at room temperature, water $(15 \mathrm{~mL})$ was added and the solution was extracted with tetrahydrofuran $(3 \times 10 \mathrm{~mL})$. The organic phase was dried under anhydrous $\mathrm{Na}_{2} \mathrm{SO}_{4}$ and the solvent was removed in rotatory evaporator. The crude product was purified by precipitation in hexane to afford the monomer (4) as a white solid. Yield: $31 \%$. ${ }^{1} \mathrm{H}$ NMR (400 MHz, DMSO-d $\left._{6}\right) \delta(\mathrm{ppm})$ : 9.73 (s, 2H); 7.61 (s, 4H); $5.79(\mathrm{~s}, 2 \mathrm{H})$; $5.49(\mathrm{~s}, 2 \mathrm{H}) ; 1.95(\mathrm{~s}, 6 \mathrm{H}) .{ }^{13} \mathrm{C}$ NMR (100 MHz, DMSO-d6) $\delta(\mathrm{ppm}): 166.5$ (2); $140.4(2) ; 134.7$ (2); 120.4 (4); 119.7 (2); 18.8 (2). Mp: $246.5^{\circ} \mathrm{C}$.

\subsection{Monomer characterization}

\subsubsection{Nuclear Magnetic Resonance (NMR)}

NMR measurements were recorded on a Bio Spin $\mathrm{GmbH}$ (Bruker Biospin, Rheinstetten, Germany), 'H: $400 \mathrm{MHz}$, ${ }^{13} \mathrm{C}: 100 \mathrm{MHz}$, in $\mathrm{CDCl}_{3}$ using tetramethylsilane (TMS) as standard or DMSO- $\mathrm{d}_{6}$. The multiplicities were attributed as: $s=$ singlet; $d=$ doublet; $t=$ triplet; $q=$ quartet; $q t=$ quintuplet; $d d=$ double dublet; $d d d=$ double double dublet e $m=$ multiplet. The hydrogen assignments were attributed based on relative integral and coupling constant $(J)$ in $\operatorname{Hertz}(\mathrm{Hz})$.

\subsubsection{Attenuated Total Reflectance-Fourier Transform Infrared Spectroscopy (ATR-FTIR)}

ATR-FTIR measurements were performed in the Bruker Alpha FTIR Spectrometer (Bruker Optics, Ettlingen, Germany). The monomers were dispensed over a diamond crystal of Attenuated Total Reflectance (ATR) accessory. A total of 64 scans were collected from $400 \mathrm{~cm}^{-1}$ to $4000 \mathrm{~cm}^{-1}$ at $4 \mathrm{~cm}^{-1}$ resolution.

\subsubsection{Ultra-High Liquid Chromatography Quadrupole Time of Flight Mass Spectrometry (UHPLC-QTOF-MS)}

High-resolution mass spectra were obtained with a Q-TOF Micro instrument (Impact II, Bruker,) in electrospray ionization positive $(\mathrm{ES}+)$ mode. A Q-TOF system was used to separate the analytes of interest. Shim-pack XR-ODS III column ( $50 \mathrm{~mm} \mathrm{X} 2 \mathrm{~mm}$ X $1.6 \mu \mathrm{m})$ was used to separate the analytes in isocratic mode with the mobile phase $40 \%$ acetonitrile $(0.1 \%$ formic acid): $60 \%$ water $(0.1 \%$ formic acid $)$ (LC, Nexera x2, Shimadzu, Tokyo, Japan). The flow rate was $0.4 \mathrm{~mL} \mathrm{~min}^{-1}$ and column temperature was $35^{\circ} \mathrm{C}$. The optimal MS parameters were as following: capillary voltage $4500 \mathrm{~V}$, source temperature $200^{\circ} \mathrm{C}$, end plate offset voltage $500 \mathrm{~V}$, mass range $(\mathrm{m} / z)$ of $60-800$ and calibration with sodium formate.

\subsubsection{Thermal polymerization kinetics}

The polymerization kinetics of monomers (2), (3) and (4) were investigated using modulated differential scanning calorimetry technique (MDSC, Q2000, TA Instruments). Three samples were analyzed with temperature range of $0-300{ }^{\circ} \mathrm{C}$ using an aluminum pan, at different heating rates 
$\left(1,2,3\right.$ and $\left.5{ }^{\circ} \mathrm{C} \min ^{-1}\right)$, with $100 \mathrm{~s}$ of period, amplitude of $\pm 1.0{ }^{\circ} \mathrm{C}$, under nitrogen atmosphere with flow rate of $50 \mathrm{~mL} \mathrm{~min} \mathrm{~m}^{-1}$ and with sample weight about $2.0 \mathrm{mg}$. The maximum temperature peak obtained from nonreverse curve was used to determine the activation energy of the polymerization according to Kissinger methodology ${ }^{[24]}$.

\section{Results and Discussions}

\subsection{Synthesis and characterization of monomers}

Bis(methacrylamide)s were prepared in one-step reaction between methacrylic anhydride and diamines as showed in Scheme 1.<smiles>CNCCCNC</smiles>

OR<smiles>NPN</smiles>

$\mathbf{R}=\left\{\begin{array}{c}\left(\mathrm{CH}_{2}\right)_{4} \\ \left(\mathrm{CH}_{2}\right)_{8} \\ \square\end{array}\right.$

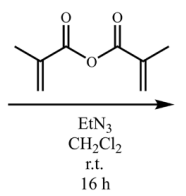<smiles>C=C(C)C(=O)N(CC)CCCN(CC)C(=O)C(=C)C</smiles><smiles>C=C(C)C(=O)NCNC(=O)C(=C)C</smiles>

$\mathbf{R}=\left\{\begin{aligned}\left(\mathrm{CH}_{2}\right)_{4} & =\text { (2) } \\ \left(\mathrm{CH}_{2}\right)_{8} & =\text { (3) } \\ & =(4)\end{aligned}\right.$

Scheme 1. Bis(methacrylamide)s synthesis.

The following monomers were synthesized with yields higher than $30 \%: N, N^{\prime}$-(propane-1,3-diyl) bis( $N$-ethyl-2-methylacrylamide) (1), $N, N^{\prime}$-(butane-1,4-diyl) bis(2-methacrylamide) (2), $N, N^{\prime}$-(octane-1,8-diyl) bis(2-methylacrylamide) (3) and $N, N^{\prime}-(1,4$ phenylene) bis(2-methylacrylamide) (4). As expected, monomer (1) having an ethyl substituent at nitrogen atom ( $N, N$-dialkylamide) was liquid, while monomers (2), (3) and (4) were white solids. The $\mathrm{C}=\mathrm{C}$ double bond axial deformation of monomers was detectable in the IR spectrum at $1610 \mathrm{~cm}^{-1}$, while $\mathrm{C}=\mathrm{O}$ stretching appeared at $1660 \mathrm{~cm}^{-1}, \mathrm{~N}-\mathrm{H}$ at $3300 \mathrm{~cm}^{-1}$ and $\mathrm{C}-\mathrm{N}$ at $1520 \mathrm{~cm}^{-1}$, confirming the synthesis of monomers (Figure S1, Supplementary Material). The signals of olefinic hydrogens of the compounds were detected by ${ }^{1} \mathrm{H}$ NMR at 5.3 and $5.8 \mathrm{ppm}$, while the $\mathrm{sp}^{2}$-hybridized $\mathrm{C}$-atoms of the acrylamide double bonds were observed at 120 and $140 \mathrm{ppm}$ in the ${ }^{13} \mathrm{C}$ NMR spectra. Complete assignments of the monomers structures were given in Figure S2 (Supplementary Material). The exact $\mathrm{m} / z$ value of each monomer was determined by UHPLC-QTOF-MS, and the structure confirmed by comparison with theoretical isotopic profile, Table 1 and Figure S3 (Supplementary Material). Error values lower than $1.2 \mathrm{ppm}$ (corresponding to a $20 \mathrm{mDa}$ ) and $\mathrm{mSigma}$ values ranged from 3.4 to 17.2 for the synthesized monomers were obtained. According to the manufacturer the err value below $5 \mathrm{ppm}$ and mSigma below 20 is considered acceptable results.

Table 1. Exact $\mathrm{m} / z$ value for the synthesized monomers.

\begin{tabular}{ccccc}
\hline Monomer & err (ppm) \\
\hline$(1)$ & Molecular Structure & 267.2068 & 0.2
\end{tabular}

(2)

$N, N^{\prime}$-(propane-1,3-diyl)bis( $N$-ethyl-2-methylacrylamide)<smiles>C=C(C)C(=O)NCCCCNC(=O)C(=C)C</smiles>

$N, N$-(butane-1,4-diyl)bis(2-methylacrylamide)

(3)<smiles>C=C(C)C(=O)NCCCCCCCCNC(=O)C(=C)C</smiles>

(4)

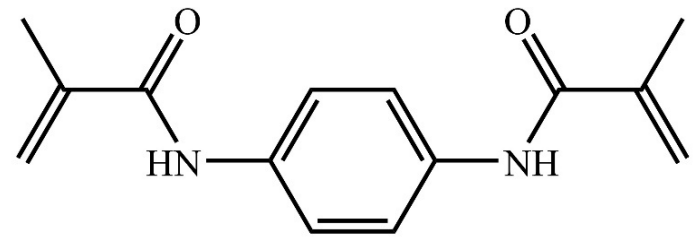




\subsection{Thermal polymerization of the monomers}

Differential scanning calorimetry (DSC) is the most used thermal analysis technique in material sciences because of its ability to provide detailed information about both the physical and energetic properties of a substance and/or formulation. However, conventional DSC was not used in this study due to shortcomings with respect to weak transitions and overlapping events, which could be solved by the use of the more sophisticated modulated DSC $(\mathrm{mDSC})$. In Figure 1 is showed the reverse, nonreverse and total heat flow of monomer (2) at a heating rate of $5{ }^{\circ} \mathrm{C}$ $\mathrm{min}^{-1}$. Total heat flow presented an endothermic event (related to monomer melting) followed by an exothermic event corresponding to the thermal polymerization. Using modulated DSC both events could be well separated, allowing the determination of the melting peak in the reverse heat flow and the polymerization enthalpy in the nonreverse heat flow (Table 2).

Unexpectedly, no exothermic event corresponding to the thermal polymerization was observed in DSC for the monomer (1) $N, N^{\prime}$-(propane-1,3-diyl)bis( $N$-ethyl-2-methylacrylamide) in the investigated temperature range. To verify the monomer photochemical polymerization $1 \mathrm{~mol} \%$ of camphorquinone
(CQ) and $1 \mathrm{~mol} \%$ of ethyl 4-dimethylaminobenzoate (EDAB) were added and was investigated by PhotoDSC ${ }^{[23]}$ (see Supplementary Material for experimental conditions). Even after $600 \mathrm{~s}$ of photopolymerization the polymerization not occurred. It is known from the literature that $N$-disubstituted methacrylamides show a very low reactivity in radical homopolymerization, which can be explained on the basis of steric effects of the substituents of the amide group ${ }^{[25]}$. This behavior was not observed neither for $N, N$-disubstituted bis(acrylamide) nor for $N$-substituted bis(methacrylamide) that were commonly used in hydrolytically stable dental adhesive formulations ${ }^{[16]}$. Monomers (2), (3) and (4) are $\mathrm{N}$-substituted bis(methacrylamide) and polymerized by radical thermal auto initiation (Table 2).

Different chemical structure of monomers resulted in activation energy $\left(\mathrm{E}_{\mathrm{a}}\right.$ ) between $-156.7 \mathrm{~kJ} \mathrm{~mol}^{-1}$ for monomer (4) to $-182.7 \mathrm{~kJ} \mathrm{~mol}^{-1}$ for monomer (2). The presence of phenyl ring in monomer (4) makes the double bond more electron-deficient and more susceptible to polymerize (lower activation energy). The more flexible structure of monomer (3) also favors the polymerization reaction and the $\mathrm{E}_{\mathrm{a}}$ is lower than monomer (2). No glass transition temperature could be observed in the second heating curve.

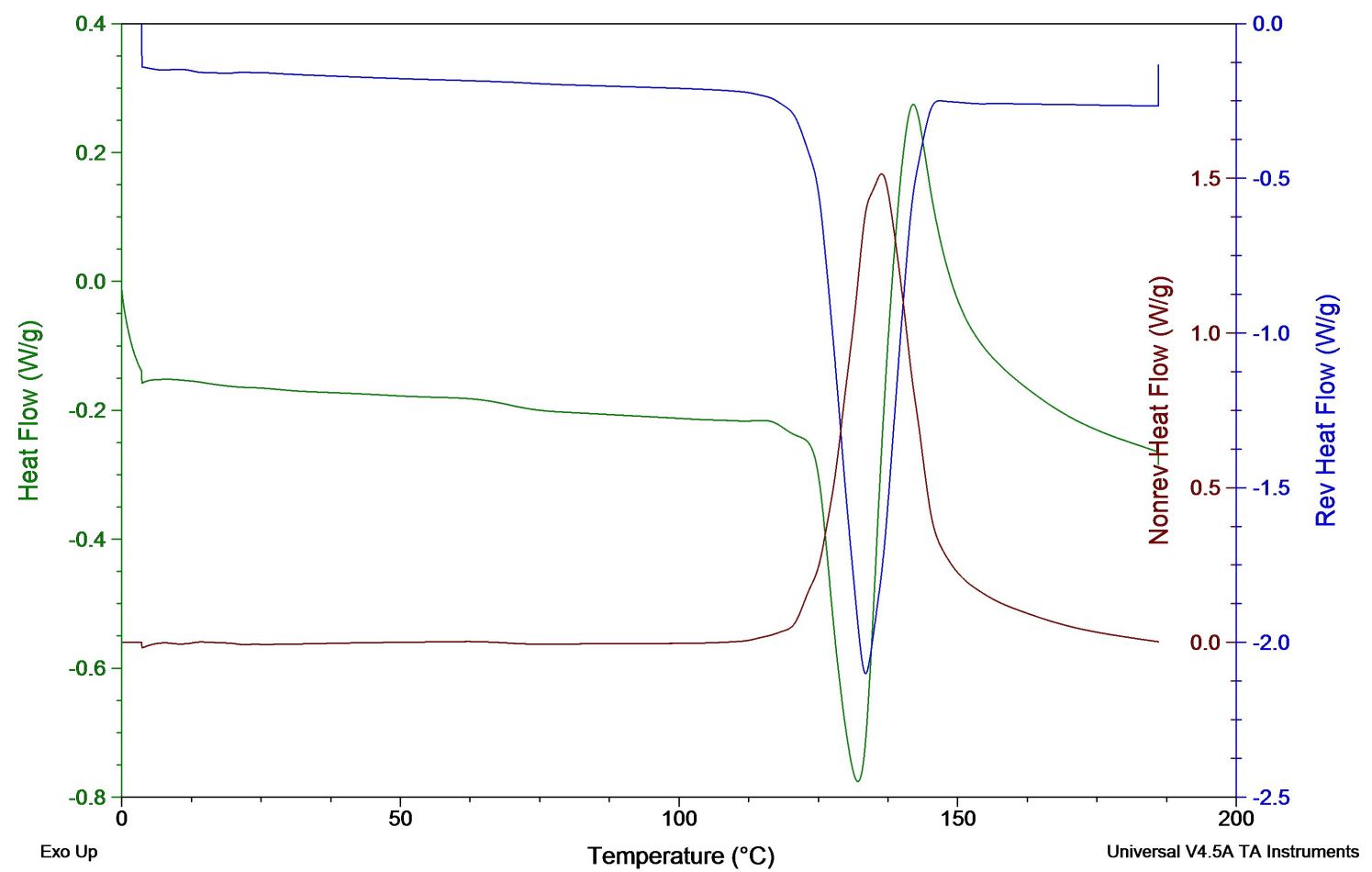

Figure 1. MDSC curves of monomer (2) at a heating rate of $5^{\circ} \mathrm{C} \mathrm{min}^{-1}$ with $100 \mathrm{~s}$ of period, amplitude of $\pm 1.0^{\circ} \mathrm{C}$.

Table 2. Results of thermal kinetics, temperature maximum $\left(\mathrm{T}_{\max }\right)$ according with heating rate, activation energy $\left(\mathrm{E}_{\mathrm{a}}-\mathrm{kJ}^{\mathrm{mol}}{ }^{-1}\right)$ and correlation constant $\left(\mathrm{R}^{2}\right)$ of monomers $(\mathrm{M})$.

\begin{tabular}{|c|c|c|c|c|c|c|}
\hline \multirow{2}{*}{$\mathbf{M}$} & \multicolumn{4}{|c|}{$\mathrm{T}_{\max }\left({ }^{\circ} \mathrm{C}\right)$} & \multirow{2}{*}{$\begin{array}{c}\mathrm{E}_{\mathrm{a}} \\
\mathrm{kJ} \mathrm{mol}^{-1}\end{array}$} & \multirow{2}{*}{$\mathbf{R}^{2}$} \\
\hline & $1^{\circ} \mathrm{C} \mathrm{min}^{-1}$ & $2^{\circ} \mathrm{C} \mathrm{min}^{-1}$ & $3^{\circ} \mathrm{C} \mathrm{min}^{-1}$ & $5^{\circ} \mathrm{C} \mathrm{min}^{-1}$ & & \\
\hline (2) & 119.31 & 121.5 & 122.5 & 129.4 & 182.7 & 0.83 \\
\hline (3) & 114.2 & 113.2 & 118.0 & 122.6 & 165.8 & 0.72 \\
\hline (4) & 259.0 & 273.0 & 268.3 & 260.4 & 156.7 & 0.64 \\
\hline
\end{tabular}




\section{Conclusions}

The synthetic route used in this study resulted in solid and liquid monomers with yields higher than $30 \%$. Moreover, the monomer (1) showed appropriate color and viscosity to dental adhesive application, but during characterization did not polymerized due to steric effects. The investigation of the thermal polymerization of monomers (2), (3) and (4) was obtained only by mDSC due to separation of cure and melting peaks and the monomer 4 showed the higher reactivity.

\section{Acknowledgements}

The authors gratefully acknowledge CAPES (Coordenação de Aperfeiçoamento de Pessoal de Nível Superior) for the scholarship (S.B.R.), Julio C.P. Vaghetti from LAMAT (Laboratório Multiusuário de Análise Térmica) for mDSC analyses and Alexsandro Dallegrave for the UHPLC-QTOF-MS analyses. The authors declare no potential conflicts of interest with respect to the authorship and/or publication of this study. This research did not receive any specific grant from funding agencies in the public, commercial, or not-for-profit sectors.

\section{References}

1. Van Landuyt, K. L., Snauwaert, J., De Munck, J., Peumans, M., Yoshida, Y., Poitevin, A., Coutinho, E., Suzuki, K., Lambrechts, P., \& Van Meerbeek, B. (2007). Systematic review of the chemical composition of contemporary dental adhesives. Biomaterials, 28(26), 3757-3785. http://dx.doi.org/10.1016/j. biomaterials.2007.04.044. PMid:17543382.

2. Pfeifer, C. S., Shelton, Z. R., Braga, R. R., Windmoller, D., Machado, J. C., \& Stansbury, J. W. (2011). Characterization of dimethacrylate polymeric networks: a study of the crosslinked structure formed by monomers used in dental composites. European Polymer Journal, 47(2), 162-170. http://dx.doi. org/10.1016/j.eurpolymj.2010.11.007. PMid:21499538.

3. Dickens, S. H., Stansbury, J. W., Choi, K. M., \& Floyd, C. J. (2003). Photopolymerization kinetics of methacrylate dental resins. Macromolecules, 36(16), 6043-6053. http://dx.doi. org $/ 10.1021 / \mathrm{ma} 021675 \mathrm{k}$.

4. Collares, F. M., Ogliari, F. A., Zanchi, C. H., Petzhold, C. L., Piva, E., \& Samuel, S. M. W. (2011). Influence of 2-hydroxyethyl methacrylate concentration on polymer network of adhesive resin. The Journal of Adhesive Dentistry, 13(2), 125-129. http:// dx.doi.org/10.3290/j.jad.a18781. PMid:21594225.

5. Ferracane, J. L. (2006). Hygroscopic and hydrolytic effects in dental polymer networks. Dental Materials, 22(3), 211-222. http://dx.doi.org/10.1016/j.dental.2005.05.005. PMid:16087225.

6. De Munck, J., Van Landuyt, K., Peumans, M., Poitevin, A., Lambrechts, P., Braem, M., \& Van Meerbeek, B. (2005). A critical review of the durability of adhesion to tooth tissue: methods and results. Journal of Dental Research, 84(2), 118-132. http://dx.doi.org/10.1177/154405910508400204. PMid: 15668328.

7. Nishiyama, N., Suzuki, K., Yoshida, H., Teshima, H., \& Nemoto, K. (2004). Hydrolytic stability of methacrylamide in acidic aqueous solution. Biomaterials, 25(6), 965-969. http://dx.doi. org/10.1016/S0142-9612(03)00616-1. PMid:14615160.

8. Ma, S. (2010). Development of a self-etching primer with higher shelf life and greater dentin bond stability. Dental Materials Journal, 29(1), 59-67. http://dx.doi.org/10.4012/ dmj.2009-078. PMid:20379014.
9. Catel, Y., Degrande, M., Le Pluart, L., Madec, P., Pham, T., \& Picton, L. (2008). Synthesis, photopolymerization and adhesive properties of new hydrolytically stable phosphonic acids for dental applications. Journal of Polymer Science. Part A, Polymer Chemistry, 47(21), 5258-5271. http://dx.doi. org/10.1002/pola.23013.

10. Liu, Y., Tjäderhane, L., Breschi, L., Mazzoni, A., Li, N., Mao, J., Pashley, D. H., \& Tay, F. R. (2011). Limitations in bonding to dentin and experimental strategies to prevent bond degradation. Journal of Dental Research, 90(8), 953-968. http:// dx.doi.org/10.1177/0022034510391799. PMid:21220360.

11. Nishiyama, N., Asakura, T., Suzuki, K., Komatsu, K., \& Nemoto, K. (2000). Bond strength of resin to acid-etched dentin studied by ${ }^{13} \mathrm{C}$ NMR: interaction between $\mathrm{N}$-methacryloyl- $\omega$-amino acid primer and dentinal collagen. Journal of Dental Research, 79(3), 806-811. http://dx.doi.org/10.1177/002203450007900 30401. PMid:10765952.

12. Nishiyama, N., Suzuki, K., Asakura, T., Komatsu, K., \& Nemoto, K. (2001). Adhesion of N-methacryloyl-omega-amino acid primers to collagen analyzed by ${ }^{13} \mathrm{C}$ NMR. Journal of Dental Research, 80(3), 855-859. http://dx.doi.org/10.1177/002203 45010800030201. PMid:11379884.

13. Torii, Y., Itou, K., Nishitani, Y., Yoshiyama, M., Ishikawa, K., \& Suzuki, K. (2003). Effect of self-etching primer containing $\mathrm{N}$-acryloyl aspartic acid on enamel adhesion. Dental Materials, 19(4), 253-258. http://dx.doi.org/10.1016/S0109-5641(02)000283. PMid:12686287.

14. Derbanne, M. A., Besse, V., Le Goff, S., Sadoun, M., \& Pham, T.-N. (2013). Hydrolytically stable acidic monomers used in two steps self-etch adhesives. Polymer Degradation \& Stability, 98(9), 1688-1698. http://dx.doi.org/10.1016/j. polymdegradstab.2013.06.006.

15. Klee, J. E., \& Lehmann, U. (2009). N-alkyl-N-(phosphonoethyl) substituted (meth)acrylamides - new adhesive monomers for self-etching self-priming one part dental adhesive. Beilstein Journal of Organic Chemistry, 5(72), 1-9. http://dx.doi. org/10.3762/bjoc.5.72. PMid:20300456.

16. Moszner, N., Zeuner, F., Angermann, J., Fischer, U., \& Rheinberger, V. (2003). Monomers for adhesive polymers, 4: synthesis and radical polymerization of hydrolytically stable crosslinking monomers. Macromolecular Materials and Engineering, 288(8), 621-628. http://dx.doi.org/10.1002/ mame. 200350003 .

17. Lichkus, A. M., Jin, X., Renn, C., Elsner, O., Szillat, F., Klee, J. E., Weber, C., Walz, U., \& Scheufler, C. A. (2017). EP Patent No 3.231.411. Paris: European Patent Office.

18. Moszner, N., Lamparth, I., Bock, T., Fischer, U. K., Salz, U., Rheinberger, V., \& Liska, R. (2013). International Patent No 2.013.034.777 A2. Hamburg: Patent Cooperation Treaty.

19. Gong, C., Wong, K.-L., \& Lam, M. H. W. (2008). Photoresponsive molecularly imprinted hydrogels for the photoregulated release and uptake of pharmaceuticals in the aqueous media. Chemistry of Materials, 20(4), 1353-1358. http://dx.doi.org/10.1021/ $\mathrm{cm} 7019526$.

20. Azodi-Deilami, S., Abdouss, M., Kordestani, D., \& Shariatinia, Z. (2014). Preparation of $N, N$ - $p$-phenylene bismethacryl amide as a novel cross-link agent for synthesis and characterization of the core-shell magnetic molecularly imprinted polymer nanoparticles. Journal of Materials Science. Materials in Medicine, 25(3), 645-656. http://dx.doi.org/10.1007/s10856013-5118-8. PMid:24338334.

21. Salz, U., Zimmermann, J., Zeuner, F., \& Moszner, N. (2005). Hydrolytic stability of self-etching adhesive systems. The Journal of Adhesive Dentistry, 7(2), 107-116. http://dx.doi. org/10.3290/j.jad.a10282. PMid:16052759. 
22. Tauscher, S., Angermann, J., Catel, Y., \& Moszner, N. (2017). Evaluation of alternative monomers to HEMA for dental applications. Dental Materials, 33(7), 857-865. http://dx.doi. org/10.1016/j.dental.2017.04.023. PMid:28528931.

23. Rodrigues, S. B., Collares, F. M., Leitune, V. C., Schneider, L. F., Ogliari, F. A., Petzhold, C. L., \& Samuel, S. M. W. (2016). Influence of hydroxyethyl acrylamide addition to dental adhesive resin. Dental Materials, 31(12), 1579-1586. http:// dx.doi.org/10.1016/j.dental.2015.10.005. PMid:26549355.

24. Huang, C., Mei, X., Cheng, Y., Li, Y., \& Zhu, X. (2014). A model-free method for evaluating theoretical error of Kissinger equation. Journal of Thermal Analysis and Calorimetry, 116(3), 1153-1157. http://dx.doi.org/10.1007/s10973-013-3624-z.

25. Otsu, T., Inoue, M., Yamada, B., \& Mori, T. (1975). Structure and reactivity of vinyl monomers: radical reactivities of $\mathrm{N}$-substituted acrylamides and methacrylamides. Journal of Polymer Science. Part C, Polymer Letters, 13(8), 505-510. http://dx.doi.org/10.1002/pol.1975.130130811.

Received: May 28, 2018

Revised: Jan. 21, 2019

Accepted: Mar. 15, 2019 


\section{Supplementary Material}

Supplementary material accompanies this paper.

Figure S1. IR spectra of monomers (1), (2), (3) and (4).

Figure S2. 1H NMR and 13C NMR of monomers (1), (2), (3) and (4).

Figure S3. Mass spectra of monomers (1), (2), (3) and (4) and theoretical isotopic profile.

This material is available as part of the online article from http://www.scielo.br/po 